\title{
Recovery of Critical Metals from Dilute Leach Solutions - Separation of Indium from Tin and Lead
}

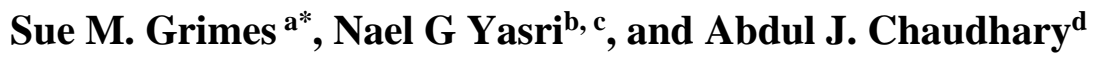

${ }^{a}$ Department of Civil \& Environmental Engineering Imperial College, London SW7 2AZ, UK.

${ }^{b}$ Department of Chemistry, Faculty of Science, University of Aleppo, Syria

${ }^{c}$ Department of Chemical and Biochemical Engineering, Western University, London, Ontario, Canada

${ }^{d}$ Institute for the Environment, Brunel University, Kingston Lane, Uxbridge, Middlesex UB8 $3 P H, U K$

*Corresponding Author: s.grimes@imperial.ac.uk

Tel: +44 (0)207 5945966

Keywords: Critical metals; Indium recovery; Cylindrical mesh electrode electrolysis cell; Electrowinning; Indium tin oxide thin films; Selective metal separation

\begin{abstract}
The strategic metal indium is recovered from solutions containing tin and lead that are typical of those obtained from leach solutions of metal component fractions of electronic waste including the leach solutions from indium tin oxide thin film conductive layers that contain only indium and tin. Almost total recovery of the metals can be achieved from nitric, perchloric and acetic acid leach solutions using a novel cylindrical mesh electrode electrolysis cell under appropriate conditions. The optimum separation of indium from tin and lead is achieved by a novel threestage process from nitric acid media in the presence of $\mathrm{SCN}^{-}$as a complexing agent. Lead is removed from dilute indium-tin-lead solutions in the first stage from $0.1 \mathrm{~mol} \mathrm{~L}^{-1}$ nitric acid solution by electrodeposition over an $8 \mathrm{~h}$ period in the absence of $\mathrm{SCN}^{-}$to give a residual solution containing a maximum of $2 \mathrm{mg} \mathrm{L}^{-1}$ of lead (97\% recovery). Tin is removed in the second stage by electrodeposition over an $8 \mathrm{~h}$ period from the solution after addition of $0.02 \mathrm{~mol}$ $\mathrm{L}^{-1} \mathrm{SCN}^{-}$to give a maximum residual electrolyte tin concentration of $3 \mathrm{mg} \mathrm{L}^{-1}$ (94\% recovery). In the third stage indium is recovered at the anode of the cylindrical mesh electrode cell as an
\end{abstract}


oxy-hydroxide phase by increasing the $\mathrm{SCN}^{-}$concentration to $0.1 \mathrm{~mol} \mathrm{~L}^{-1}$ and carrying out the electrolysis for a period of $24 \mathrm{~h}$ to give a residual solution containing $1 \mathrm{mg} \mathrm{L}^{-1}$ of indium (98\% recovery).

\section{Introduction}

Indium is an essential material in industry and is important in modern economies, but increasing consumption of the metal, particularly in electronics, has led to it being identified as a critical metal subject to available supply risks [1-3]. Methodologies that consider factors such as supply risk, environmental implications and vulnerability to supply restriction have been devised to determine metal criticality [4,5] and indium has been listed as near-critical in the short-term in a United States Department of Energy Report (2011) on Critical Materials Strategy [6]. Mitigation of these supply risks is limited because substitution of the metal is possible for only a few applications and because recycling of indium is currently restricted to only a few manufacturing residues [7].

The major use of indium is in the electronics and photovoltaics industries. Almost $70 \%$ of the annual supply of the metal is used in the production of transparent conductive indium tin oxide (ITO) films, with an $\mathrm{In}_{2} \mathrm{O}_{3}: \mathrm{SnO}_{2}$ mass ratio of approximately 9:1 [8], used in electrical and electronic devices. The mean indium content of these thin films is between 450 and $870 \mathrm{mg} \mathrm{m}^{-2}$ [9]. Indium can also be found in copper-indium-gallium-selenide/sulfide (CIGS) thin film photovoltaics in solar cells. The use of these materials in the solar cell market, however, is diminishing and the total use of these materials, along with cadmium telluride, had dropped to less than $8 \%$ of the photovoltaics used in 2012 [10]. In addition to the use of indium in thin films, very low percentages of indium are present along with lead in tin metal and tin ore residues including, for example, most solders used in electronic equipment.

Difficulties in the development of recycle methodologies for the recovery of indium from secondary and low grade primary sources arise from: (i) leaching of the metal from waste and low grade primary sources and particularly ITO residues generally results in solutions containing the critical metal in very dilute solution $(<50 \mathrm{mg} / \mathrm{L})$ and /or (ii) the presence of other metals such 
tin, lead and zinc. Processes have been developed to recover indium along with other metals such as copper, tin, gallium and lead from secondary sources such as alloy scraps [11], solar cells [12], etching solutions [13], hydrometallurgical leach solutions [14] and waste electrical and electronic equipment (WEEE), including LCD screens [15-17]. Recovery methodologies tend to be based on a combination of steps usually involving leaching or occasionally high temperature chlorination [12] followed by additional processes that include chemical precipitation [14-16], solvent extraction [13] cementation [18] or electro-recovery [11,19]. Jiang et al. [20], for example, recovered about $95 \%$ of the indium from a typical mineral leach solution containing about $60 \mathrm{mg} \mathrm{L}^{-1}$ indium as a phosphate precipitate $\left(\mathrm{NaIn}_{3}\left(\mathrm{P}_{3} \mathrm{O}_{10}\right)_{2} \cdot 12 \mathrm{H}_{2} \mathrm{O}\right)$ containing impurity metals that were removed in the following treatment steps: (i) $\mathrm{NaOH}$ leaching, (ii) hot $\mathrm{H}_{2} \mathrm{SO}_{4}$ treatment, (iii) extraction by D2EHPA, and (iv) cementation of In metal with zinc powder. Indium has also been obtained as part of tin and lead recovery processes that included a step of cementing indium sponge from a final leach solution with aluminium or zinc [21]. A multi-step chemical process for the recovery and separation of indium, tin and lead from scrap wire has been reported [11] that involved acid/alkali leaching, followed by cementation of lead with indium powder and the precipitation of tin, as tin oxide, with indium being recovered from the final solution by precipitation as a phosphate or by cementation of a metallic indium sponge with Zn powder.

A number of methods of obtaining solutions of indium tin oxide films have been described including chloride volatilisation [22, 23], alkali leaching with molten $\mathrm{NaOH}$ [24] and sodium hydroxide solutions [25], acid leaching, using for example $\mathrm{HCl}, \mathrm{HNO}_{3}, \mathrm{H}_{2} \mathrm{SO}_{4}$ and $\mathrm{HF}$ [26-31], assisted in some cases by physical methods such as high energy ball-milling [29], microwaveassisted digestion [30] and cross-current leaching [31]. Recovery of indium leached into solution by these methods is achieved through cementation with a metal such as $\mathrm{Zn}$ to give indium sponge [24, 26, 28, 31]; precipitation as an indium hydroxide phase [25, 29]; and concentration in solution by solvent extraction using standard procedures [27] or as part of a mechanochemical extraction of indium from LCD glass with aminopolycarbonates [30].

The use of electrodeposition in recovering and recycling metals including indium is well established [18, 32-35] but the efficiency of the separation and recovery of the metals can be 
affected by the presence of other species in the electrolyte. The electrochemical recovery of indium in particular is strongly influenced by the composition of the electrolyte, the indium concentration in the electrolyte, and the presence of complexing agents [15,16, 36,37]. For example, indium deposition is about $10^{5}$ times faster from solutions in which the basic ion $\left[\mathrm{In}\left(\mathrm{H}_{2} \mathrm{O}\right)_{5} \mathrm{OH}\right]^{2+}$ predominates than it is from acidic solutions in perchloric acid where the indium is present as $\operatorname{In}\left(\mathrm{H}_{2} \mathrm{O}\right){ }_{6}^{3+}[38]$. In earlier work [39,40] the authors have described the development of electrochemical cells designed to monitor trace levels of metals, to recover metals from dilute solution [41], to separate cobalt and nickel [42], and to simultaneously remove metals and degrade organic contaminants in effluent streams [43-45].

We now report on the use of a novel electrolysis system for the recovery and separation of indium, tin and lead from very dilute solutions that would model the concentrations of indium contained in solutions that are typical of many leaching processes used in treatment of electronic wastes to recover indium from components such as indium tin oxide thin films.

\section{Experimental Section}

\subsection{Materials and Methods}

Chemicals used were of reagent grade or higher obtained from Merck and Fluka and used without further purification. Reagent grade indium(III) chloride, tin(II) chloride dihydrate and lead(II) nitrate were used to prepare metal solutions containing $50 \mathrm{mg} \mathrm{L}^{-1}$ each of $\mathrm{In}, \mathrm{Sn}$ and $\mathrm{Pb}$ in acetic, nitric and perchloric acids for use as electrolytes in studies on the separation and recovery of the metals from solutions of different acid strengths.

\subsection{The Cylindrical Mesh Electrode Electrolysis Cell}

Electrochemical recovery and separation of the metals was performed in batch experiments using a cylindrical mesh electrode electrolysis cell (Figure 1) designed to maximise recovery of metals from dilute solution. The cell was developed from one used in earlier work to achieve simultaneous recovery of metals and destruction of organic components from dilute solution [4346]. It consists of a Pyrex vessel (with an outer diameter $16 \mathrm{~cm}$ and height $30 \mathrm{~cm}$ ) containing 
two acid-resistant cylindrical titanium mesh anodes (diameters $3.8 \mathrm{~cm}$ and $10.6 \mathrm{~cm}$, and height $21 \mathrm{~cm}$ ) coated with iridium oxide, on either side of a cylindrical mild steel mesh cathode (diameter $7.8 \mathrm{~cm}$, height $21 \mathrm{~cm}$ ). In the sequence, anode-cathode-anode, the gaps between the inner anode and the cathode and between the cathode and the outer anode are $2 \mathrm{~cm}$ and $1.4 \mathrm{~cm}$ respectively. Mesh electrodes are used to improve electrodeposition by providing a large cathode surface area $\left(0.109 \mathrm{~m}^{2}\right)$ and by reducing the effective diffusion barrier at the electrodes [47]. All experiments were performed at a constant cathodic current density of $13.7 \mathrm{~A} \mathrm{~m}^{-2}(1.5 \mathrm{~A})$ and at ambient temperature.

During the electrolysis in the cylindrical mesh electrode cell, electrolyte samples were collected every hour over a period of $8 \mathrm{~h}$ (or for $24 \mathrm{~h}$, when stated) for analysis of residual metal ions by flame atomic absorption spectrometry using a Perkin Elmer 2380 spectrometer. Recovery was assumed to be complete when the residual ion concentration of the metals was below the detection limit of the spectrometer.

X-ray diffraction data were obtained using a Rigaku ULTIMA IV diffractometer with $\mathrm{Cu} \mathrm{K} \alpha$ radiation.

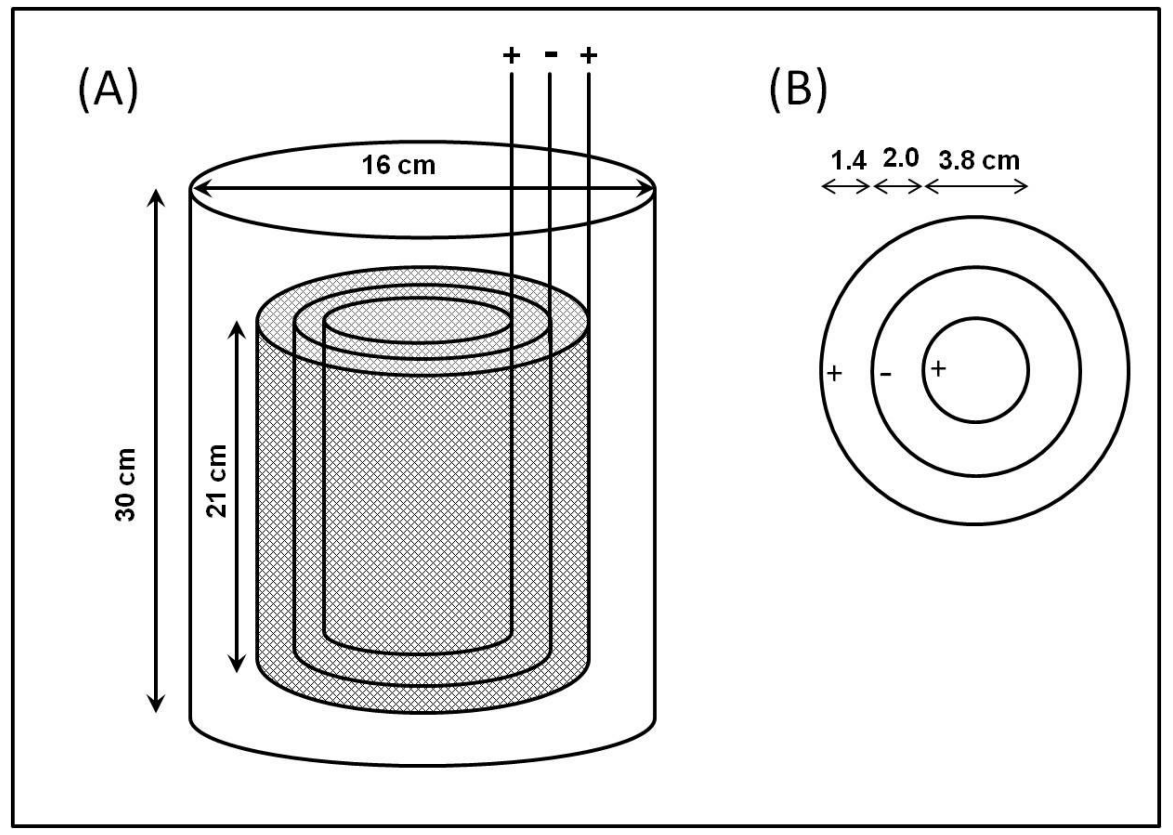

Figure 1: Schematic of the cylindrical mesh electrode electrolysis cell. 


\subsection{Separation and recovery of indium from single, binary and tertiary metal solutions}

To determine the conditions under which indium can be separated and recovered from tin and lead in dilute leach solutions, the following studies were carried out.

\subsubsection{Effect of the presence of tin and lead on indium separation and recovery}

The effect of the presence of tin and lead on the separation and removal of indium from solutions containing In $\left(50 \mathrm{mg} \mathrm{L}^{-1}\right)$, in binary mixtures with $\mathrm{Sn}\left(50 \mathrm{mg} \mathrm{L}^{-1}\right)$ and with $\mathrm{Pb}\left(50 \mathrm{mg} \mathrm{L}^{-1}\right)$, separately, and in a tertiary mixture containing $\mathrm{Sn}$ and $\mathrm{Pb}\left(50 \mathrm{mg} \mathrm{L}^{-1}\right.$ each $)$ in three acid media nitric and perchloric acids (in concentrations of $0.01,0.05,0.1,0.5$ and $1.0 \mathrm{~mol} \mathrm{~L}^{-1}$ ) and acetic acid (in concentrations of $0.05,0.1,0.5$ and $1.0 \mathrm{~mol} \mathrm{~L}^{-1}$ ) were investigated. Because of the low conductivity of $0.01 \mathrm{~mol} \mathrm{~L}^{-1}$ acetic acid this concentration was not used in the study. Recovery of indium from solutions containing In $\left(50 \mathrm{mg} \mathrm{L}^{-1}\right)$ alone, in the three acid media, were used as controls and the percentage recoveries of indium from the mixed metal solutions and the controls are in Table 1.

\subsubsection{Effect of acid strength on metal separation and recovery}

The effects of the choice of acid leach solution in different concentrations using nitric and perchloric acids (in concentrations of 0.01, 0.05, 0.1, 0.5 and $1.0 \mathrm{~mol} \mathrm{~L}^{-1}$ ), and acetic acid (in concentrations of $0.05,0.1,0.5,1.0$ and $5 \mathrm{~mol} \mathrm{~L}^{-1}$ ) on the separation and removal of the metals from mixed metal solutions, containing $50 \mathrm{mg} \mathrm{L}^{-1}$ of each metal, in the cylindrical mesh electrode electrolysis cell, over a period of 8 hours electrolysis, were investigated and the results are in Table 2.

\subsubsection{Effect of thiocyanate ions on metal separation and recovery}

Although the chemical behaviour of tin(II) and In(III) are similar, tin, unlike indium, forms relatively strong complexes with thiocyanate $\left(\mathrm{SCN}^{-}\right)$ions and the presence of $\mathrm{SCN}^{-}$is known to improve the electrodeposition of this metal on a cathode by preventing oxidation and hydrolysis of the $\mathrm{Sn}^{2+}$ ions in solution. [48,49]. The influence of thiocyanate as a complexing agent on the electrodeposition and separation of indium, tin and lead from mixed metal solutions in the cylindrical mesh electrode cell was studied in nitric acid media, over an 8-h period in the presence of thiocyanate ions (added as reagent grade KSCN) for two different systems viz: (a) 
changing the nitric acid concentration $\left(0.05-0.5 \mathrm{~mol} \mathrm{~L}^{-1}\right)$ at a constant $\mathrm{SCN}^{-}$concentration of $0.05 \mathrm{~mol} \mathrm{~L}^{-1}$, and (b) changing the $\mathrm{SCN}^{-}$concentration $\left(0.02-0.1 \mathrm{~mol} \mathrm{~L}^{-1}\right)$ at a constant nitric acid concentration of $0.1 \mathrm{~mol} \mathrm{~L}^{-1}$. The results (Table 3) are compared with those of control solutions, for both systems, in which no $\mathrm{SCN}^{-}$was added. The anodic deposits obtained from nitric acid solutions containing $0.1 \mathrm{~mol}^{\mathrm{L}-1} \mathrm{SCN}^{-}$were identified by their X-ray diffraction patterns.

\subsection{Development of a process for selective separation and recovery of indium from a mixed metal In:Sn:Pb system}

Electrolyte solutions (2L) containing $50 \mathrm{mg} \mathrm{L}^{-1}$ each of $\mathrm{In}, \mathrm{Sn}$ and $\mathrm{Pb}$ in $0.1 \mathrm{~mol} \mathrm{~L}^{-1}$ nitric acid were used to develop a three-phase recovery process for the efficient separation and recovery of indium. In the first phase the effect of nitric acid concentration on the deposition of lead (Figure 2) was exploited in an 8 hour electrolysis in the absence of a complexing agent to remove $\mathrm{Pb}$ on the cathode. The electrodes were then removed, and, using clean electrodes, a second phase of electrolysis was carried out over an $8 \mathrm{~h}$ period in the presence of $0.02 \mathrm{~mol} \mathrm{~L}^{-1} \mathrm{SCN}^{-}$to remove $\mathrm{Sn}$ at the cathode. At this concentration of $\mathrm{SCN}^{-}$none of the indium present in solution is deposited on the electrodes. The electrolysis was then extended in the third phase for a further 24 hours, using the electrolyte after both lead and tin have been removed but with a higher concentration of $\mathrm{SCN}^{-}\left(0.1 \mathrm{~mol} \mathrm{~L}^{-1}\right)$ which results in the recovery of indium at the anode. The efficiency of each phase was determined by measurement of the residual metal concentration in solution after each of the phases in the process. The residual maximum concentrations at the conclusion of each phase were $2 \mathrm{mg} \mathrm{L}^{-1} \mathrm{~Pb}$ after phase 1; $3 \mathrm{mg} \mathrm{L}^{-1} \mathrm{Sn}$ after phase 2; and $1 \mathrm{mg} \mathrm{L}^{-1} \mathrm{In}$ after phase 3 . 
Table 1: Percentage recovery of indium from different acid media

\begin{tabular}{|c|c|c|c|c|}
\hline \multirow{3}{*}{$\begin{array}{c}\mathrm{HNO}_{3} \\
\text { Concentration } \\
\left(\mathrm{mol} \mathrm{L}^{-1}\right)\end{array}$} & \multicolumn{4}{|c|}{ Recovery of indium from nitric acid $(\%)$} \\
\hline & \multirow{2}{*}{$\begin{array}{c}\text { Control } \\
\text { In only }\end{array}$} & \multicolumn{2}{|c|}{ Binary Mixture } & \multirow{2}{*}{$\begin{array}{c}\text { Tertiary Mixture } \\
\text { with both } \mathrm{Sn} \text { and } \mathrm{Pb}\end{array}$} \\
\hline & & with Sn & with $\mathbf{P b}$ & \\
\hline 0.01 & 42.0 & 99.4 & 79.4 & 97.0 \\
\hline 0.05 & 15.8 & 98.1 & 62.6 & 65.8 \\
\hline 0.1 & 0.0 & 0.0 & 0.0 & 0.0 \\
\hline 0.5 & 0.0 & 0.0 & 0.0 & 0.0 \\
\hline 1.0 & 0.0 & 0.0 & 0.0 & 0.0 \\
\hline \multirow{3}{*}{$\begin{array}{l}\mathrm{HClO}_{4} \\
\text { Concentration } \\
\left(\mathrm{mol} \mathrm{L}^{-1}\right)\end{array}$} & \multicolumn{4}{|c|}{ Recovery of indium from perchloric acid (\%) } \\
\hline & Control & \multicolumn{2}{|c|}{ Binary Mixture } & Tertiary Mixture \\
\hline & In only & with Sn & with Pb & with both $\mathrm{Sn}$ and $\mathrm{Pb}$ \\
\hline 0.01 & 92.0 & 98.8 & 95.6 & 94.8 \\
\hline 0.05 & 9.2 & 95.0 & 85.0 & 73.8 \\
\hline 0.1 & 6.6 & 91.6 & 41.8 & 21.8 \\
\hline 0.5 & 0.0 & 4.0 & 0.0 & 0.0 \\
\hline 1.0 & 0.0 & 0.0 & 0.0 & 0.0 \\
\hline \multirow{3}{*}{$\begin{array}{l}\mathrm{CH}_{3} \mathrm{COOH} \\
\text { Concentration } \\
\quad\left(\mathrm{mol} \mathrm{L}^{-1}\right)\end{array}$} & \multicolumn{4}{|c|}{ Recovery of indium from acetic acid (\%) } \\
\hline & Control & \multicolumn{2}{|c|}{ Binary Mixture } & Tertiary Mixture \\
\hline & In only & with Sn & with $\mathbf{P b}$ & with both $\mathrm{Sn}$ and $\mathrm{Pb}$ \\
\hline 0.05 & 97.4 & 98.2 & 99.2 & 98.8 \\
\hline 0.1 & 97.2 & 98.0 & 99.6 & 99.0 \\
\hline 0.5 & 99.0 & 98.0 & 97.6 & 98.4 \\
\hline 1.0 & 98.0 & 97.6 & 94.6 & 96.8 \\
\hline
\end{tabular}


Table 2: Percentage removal of indium, tin and lead from mixed metal solutions in different strengths of acid media

\begin{tabular}{|c|c|c|c|}
\hline \multirow{2}{*}{$\begin{array}{c}\mathrm{HNO}_{3} \\
\text { Concentration } \\
\left(\mathrm{mol} \mathrm{L}^{-1}\right)\end{array}$} & \multicolumn{3}{|c|}{$\begin{array}{c}\text { Percentage removal of In, } \mathrm{Sn} \text { and } \mathrm{Pb} \text { from mixed metal solutions in } \\
\text { nitric acid }(\%)\end{array}$} \\
\hline & Indium & Tin & Lead \\
\hline 0.01 & 97.0 & 74.0 & 97.0 \\
\hline 0.05 & 65.8 & 54.4 & 97.0 \\
\hline 0.1 & 0.0 & 4.4 & 97.0 \\
\hline 0.5 & 0.0 & 0.0 & 70.0 \\
\hline 1.0 & 0.0 & 0.0 & 0.0 \\
\hline \multirow{2}{*}{$\begin{array}{c}\mathrm{HClO}_{4} \\
\text { Concentration } \\
\left(\mathrm{mol} \mathrm{L}^{-1}\right)\end{array}$} & \multicolumn{3}{|c|}{$\begin{array}{c}\text { Percentage removal of } \mathrm{In}, \mathrm{Sn} \text { and } \mathrm{Pb} \text { from mixed metal solutions in } \\
\text { perchloric acid }(\%)\end{array}$} \\
\hline & Indium & Tin & Lead \\
\hline 0.01 & 94.8 & 95.7 & 95.0 \\
\hline 0.05 & 73.8 & 78.4 & 94.0 \\
\hline 0.1 & 21.8 & 61.3 & 94.0 \\
\hline 0.5 & 0.0 & 0.0 & 94.0 \\
\hline 1.0 & 0.0 & 0.0 & 90.0 \\
\hline \multirow{2}{*}{$\begin{array}{c}\mathrm{CH}_{3} \mathrm{COOH} \\
\text { Concentration } \\
\quad\left(\mathrm{mol} \mathrm{L}^{-1}\right)\end{array}$} & \multicolumn{3}{|c|}{$\begin{array}{l}\text { Percentage removal of } \mathrm{In}, \mathrm{Sn} \text { and } \mathrm{Pb} \text { from mixed metal solutions in } \\
\text { acetic acid }(\%)\end{array}$} \\
\hline & Indium & Tin & Lead \\
\hline 0.05 & 98.8 & 97.3 & 99.0 \\
\hline 0.1 & 99.0 & 96.4 & 98.0 \\
\hline 0.5 & 98.4 & 88.8 & 98.0 \\
\hline 1.0 & 96.8 & 88.4 & 98.0 \\
\hline 5.0 & 52.7 & 36.8 & 98.3 \\
\hline
\end{tabular}


Table 3: Percentage removal of indium, tin and lead at the cathode from a $0.1 \mathrm{~mol} \mathrm{~L}^{-1} \mathrm{HNO}_{3}$ solution, with varying concentration of $\mathrm{SCN}^{-}\left(0-0.1 \mathrm{~mol} \mathrm{~L}^{-1}\right)$

\begin{tabular}{|c|c|c|c|c|}
\hline \multirow[t]{2}{*}{$\begin{array}{c}\mathrm{SCN}^{-} \\
\left(\mathrm{mol} \mathrm{L}^{-1}\right)\end{array}$} & \multirow{2}{*}{$\begin{array}{c}\text { Deposition } \\
\text { at }\end{array}$} & \multicolumn{3}{|c|}{$\begin{array}{l}\text { Removal of metal ( \%) from a mixed metal solution in } 0.1 \mathrm{~mol} \\
\mathrm{~L}^{-1} \text { of nitric acid at variable } \mathrm{SCN}^{-} \text {concentration }\end{array}$} \\
\hline & & Indium & Tin & Lead \\
\hline $\begin{array}{c}\text { Control } \\
{\left[\mathrm{No} \mathrm{SCN}^{-}\right]}\end{array}$ & \multirow{4}{*}{$\begin{array}{l}\text { Cathode } \\
\text { after } 8 \mathrm{~h}\end{array}$} & 0.0 & 4.4 & 97.0 \\
\hline 0.02 & & 0.0 & 93.2 & 78.0 \\
\hline 0.05 & & 0.0 & 56.4 & 79.0 \\
\hline 0.1 & & 0.0 & 49.2 & 81.0 \\
\hline 0.1 & $\begin{array}{l}\text { Anode } \\
\text { after } 8 \mathrm{~h} \\
\text { after } 24 \mathrm{~h}\end{array}$ & 71.0 & 0.0 & 0.0 \\
\hline
\end{tabular}

\section{Results and Discussion}

The data in Tables 1-3 on the combined effects of acid concentration and the presence of the complexing agent $\mathrm{SCN}^{-}$on the recovery of indium from mixed metal systems containing tin and lead in a cylindrical mesh electrode electrolysis cell were used to identify nitric acid solutions as the preferred medium for the efficient recovery and separation of indium from these solutions in a three-stage process. In the first stage the effect of nitric acid concentration on the deposition of lead (Figure 2) was exploited to deposit only lead at the cathode over an 8 hour period of electrolysis. The beneficial effects of the presence of the $\mathrm{SCN}^{-}$ion as a complexing agent are then used to maximise the deposition of tin at the cathode over a period of $8 \mathrm{~h}$ in stage 2 , and the advantage of being able to remove indium on the anode as an indium oxy hydroxide phase by electrolysis of a period of $24 \mathrm{~h}$ completes the recovery and separation in stage 3 . The cylindrical mesh electrode electrolysis cell which was designed to maximise recovery of metals from dilute 
solutions has been used to achieve the recovery and separation of the critical metal indium from dilute solutions containing tin, lead or a mixture of tin and lead in the following three stage process:
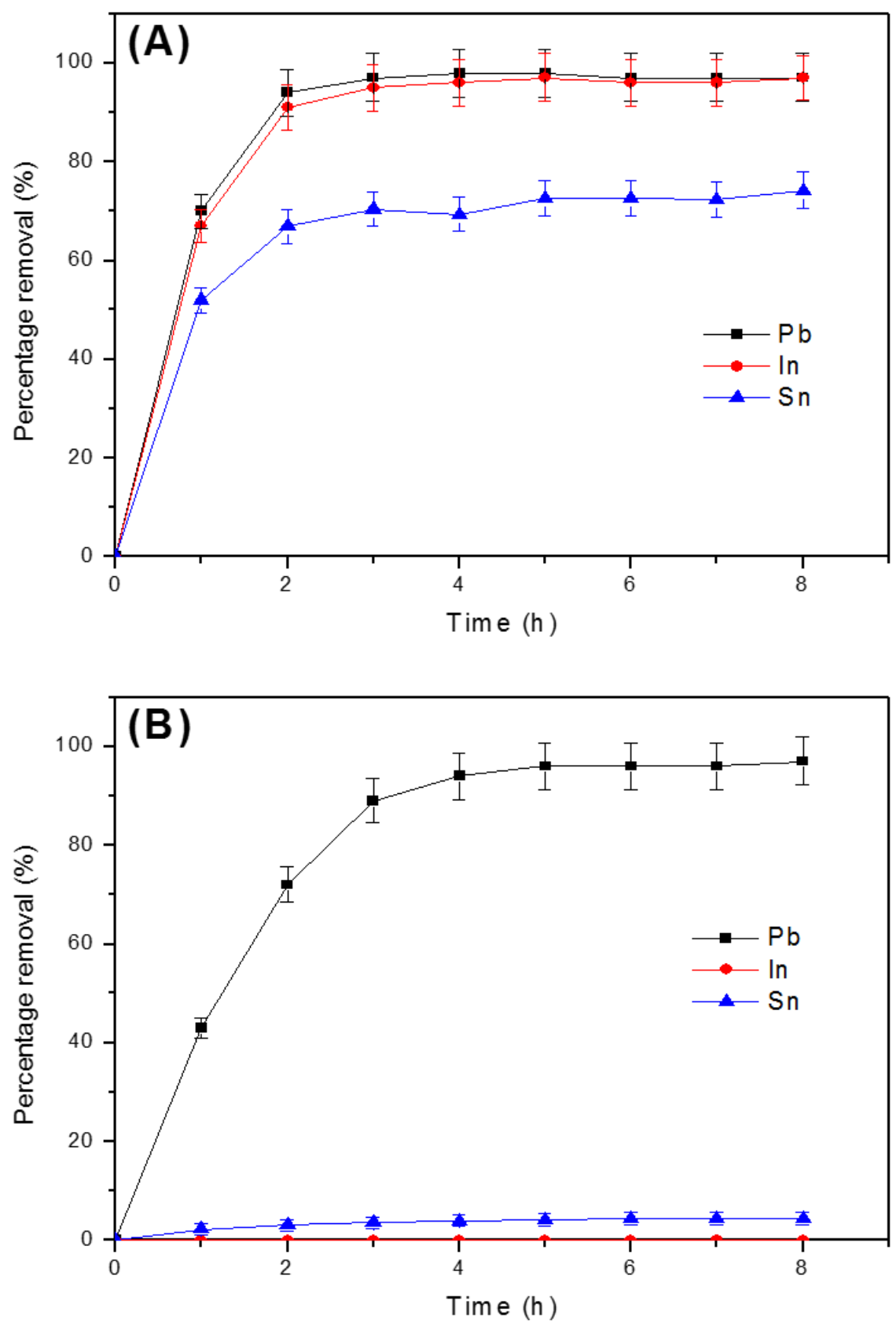

Figure 2: Percentage of indium $(\mathrm{In})$, tin( $(\mathrm{Sn})$, and lead $(\mathrm{Pb})$ removal from: (A) $0.01 \mathrm{~mol} \mathrm{~L}^{-1}$ $\mathrm{HNO}_{3}$, and (B) $0.1 \mathrm{~mol} \mathrm{~L}^{-1} \mathrm{HNO}_{3}$ 
Stage 1: Lead is first removed (97\%) from dilute mixed metal (indium-tin-lead) solutions in 0.1 mol L ${ }^{-1}$ nitric acid by electrodeposition in the cylindrical mesh electrode electrolysis cell, over an 8 hour period, to give a residual solution containing a maximum of $2 \mathrm{mg} \mathrm{L}^{-1}$ of lead.

Stage 2: The electrodes used in stage 1 are replaced with clean electrodes and tin is completely removed from the residual electrolyte solution from stage 1 after addition of $0.02 \mathrm{~mol} \mathrm{~L}^{-1} \mathrm{SCN}^{-}$ by electrodeposition on the cathode over an 8 hour period to give an electrolyte in which the residual tin concentration is a maximum of $3 \mathrm{mg} \mathrm{L}^{-1}$.

Stage 3: Because cathodic deposition of indium from dilute solution in nitric acid is poor the strategic metal is then recovered from the residual electrolyte from stage 2 after increasing the $\mathrm{SCN}^{-}$concentration in the solution to $0.1 \mathrm{~mol} \mathrm{~L}^{-1}$ by electrolysis over a $24 \mathrm{~h}$ period to deposit indium at the anode, identified by X-Ray diffraction as an oxy-hydroxide phase (Figure 3), giving a residual solution containing a maximum of $1 \mathrm{mg} \mathrm{L}^{-1}$ of indium.

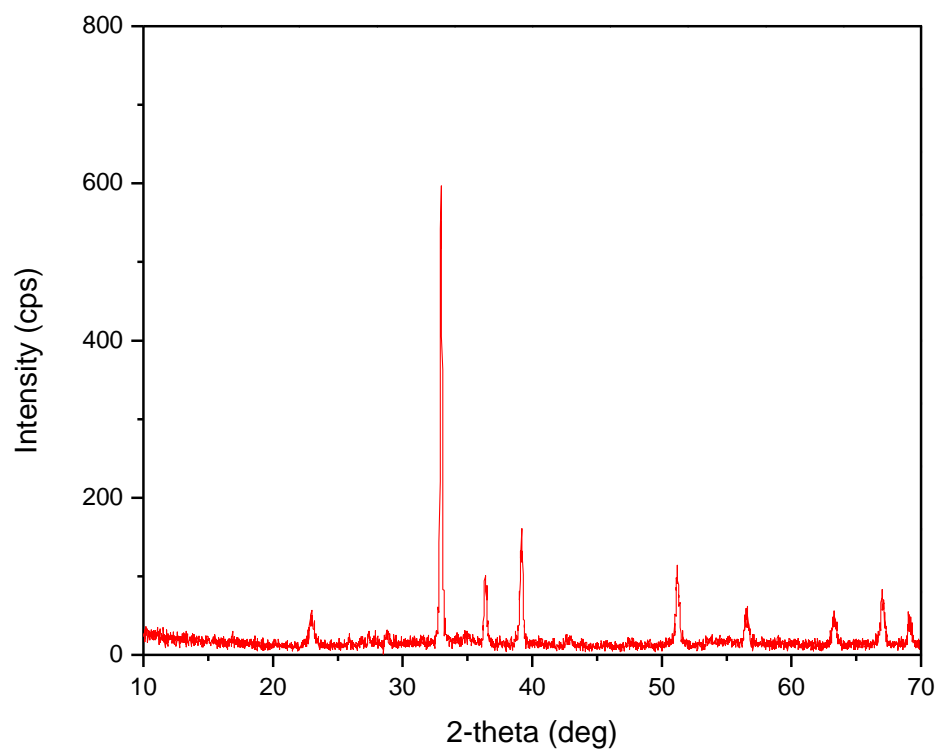

Figure 3: XRD pattern of the precipitate from at the anode following the third phase separation that assigned to indium(III) oxy-hydroxide phase. 


\section{Conclusion}

An electrolysis cell containing cylindrical mesh electrodes developed to maximise the recovery of metals from dilute solutions is used to maximise the recovery of indium, tin, and lead from acid leach media under appropriate conditions. The design of the cylindrical mesh electrodes used in the cell reduces the effective diffusion barrier at the electrodes and maximises both the deposition of tin and lead on the cathode and of an indium hydroxide phase on the anode. The greater deposition efficiencies achieved in the cell permits its use in the removal of metals from very dilute solutions leaving very low levels of residual metals in solution to be dealt with on disposal of any spent electrolytes. In particular the recovery and separation of the critical metal, indium from dilute leach solutions using the cell can be achieved by careful control of the acidity of the solution and of the concentration of the complexing ion $\left(\mathrm{SCN}^{-}\right)$in the electrolyte. Any commercial process based on this technology would achieve the recovery of indium, with minimal losses of the critical material, separated from the tin present in the leach solution that is recovered in a separate stage of the process as a cathodic deposit of the metal.

\section{Acknowledgements}

We acknowledge the support of an EPSRC/LINK WMR3 grant (GR/L03217) with Fluid Dynamics International Limited. We wish to thank Aleppo University for a scholarship to NY and Professor. J. D. Donaldson for all his advice and support

\section{References}

[1] EU Commission, "Report on Critical Raw Materials for the EU" Report of the Ad-hoc Working Group on Defining Critical Raw Materials, (2014). DG Enterprise \& Industry, Brussels May 2014

[2] J.P. Sykes, J.P. Wright, A. Trench, Applied Earth Science, 125 (1) (2016) 3-20.

[3] L. Erdmann, T.E. Graedel, Environmental Science \& Technology, 45 (2011) 7620-7630.

[4] T.E. Graedel, R. Barr, C. Chandler, T. Chase, J. Choi, L. Christoffersen, E. Friedlander, C. Henly, C. Jun, N.T. Nassar, D. Schechner, S. Warren, M.-y. Yang, C. Zhu, Environmental Science \& Technology, 46 (2012) 1063-1070.

[5] A. Weiser, D.J. Lang, T. Schomerus, A. Stamp, Journal of Cleaner Production, 94 (2015) 376-393.

[6] U.S. Department of Energy Critical Materials Strategy - 2011 DOE/PI-0009 (2012) U.S Department of Energy, Washington DC 
[7] M. Buchert, D. Schüler, D. Bleher, Sustainable Innovation and Technology Transfer Industrial Sector Studies, United Nations University, United Nations Environment Programme 2009, pp. 81.

[8] K. Zhang, Y. Wu, W. Wang, B. Li, Y. Zhang, T. Zuo, Resources, Conservation and Recycling, 104, Part A (2015) 276-290.

[9] M. Buchert, A. Manhart, D. Bleher, D. Pingel, Oeko-Institut e.V., Freiburg, Germany (2012), $1-80$

[10] M.Marwede, A.Reller J.Industrial Ecology, 18(2) (2014) 254-267

[11] M.A. Barakat, Hydrometallurgy, 49 (1998) 63-73.

[12] A.M.K. Gustafsson, B.-M. Steenari, C. Ekberg, Separation Science and Technology, 50 (2015) 1-9.

[13] W.-S. Chou, Y.-H. Shen, S.-J. Yang, T.-C. Hsiao, L.-F. Huang, R Environmental Progress \& Sustainable Energy, 35(3), (2016) 758-763

[14] M. Martin, E. Janneck, R. Kermer, A. Patzig, S. Reichel, Minerals Engineering, 75 (2015) 94-99.

[15] D. Fontana, F. Forte, R. De Carolis, M. Grosso, Waste Management, 45 (2015) 325-333.

[16] A.V.M. Silveira, M.S. Fuchs, D.K. Pinheiro, E.H. Tanabe, D.A. Bertuol, Waste Management, 45 (2015) 334-342.

[17] X. Zeng, F. Wang, X. Sun, J. Li, ACS Sustainable Chemistry \& Engineering, 3 (2015) 1306-1312.

[18] Y. Li, Z. Liu, Q. Li, Z. Liu, L. Zeng, Hydrometallurgy, 105 (2011) 207-212.

[19] W.-L. Chou, Y.-H. Huang, Journal of Hazardous Materials, 172 (2009) 46-53.

[20] J. Jiang, D. Liang, Q. Zhong, Hydrometallurgy, 106 (2011) 165-169.

[21] A.M. Alfantazi, R.R. Moskalyk, , Minerals Engineering, 16 (2003) 687-694.

[22] K-S.Park, W.Sato, G.Grause, T.Kameda, T.Yoshioka Thermochim.Acta 493, (2009) 105108

[23] K. Takahashi, A. Sasaki, G. Dodbiba, J. Sadaki, N. Sato, T. Fujita: Metall. Mater. Trans. A 40 (2009) 891-900.

[24] J-C.Park, Bull. Korean Chem.Soc. 29(1), (2008) 255-256

[25] K.N. Han, S.Kondoju, K Park and H-M.Kang, Geosystem Engineering 5(4), (2002) 93-98

[26] S-J.Hsieh, C-C.Chen, W.C.Say Mater Sci. and Engineering B 158 (2009) 82-87

[27] S.Virolainen, D.Ibana, E.Paatero, Hydrometallurgy, 107, (2011), 56-61

[28] Y.Li, Z.Liu, Q.Li, Z.Liu, L.Zeng Hydrometallurgy 105, (2011) 207-212

[29] C.H.Lee, M-K.Jeong, M.F.Kilicaslan, J-H.Lee, H-S.Hong Waste Management 33 (2013) 730-734.

[30]H.Hasegawa, I.M.M.Rahman, Y.Egawa, H.Sawai, Z.Begum, T.Maki, S.Mizutani Microchemical Journal 106 (2013), 289-294

[31]L.Rocchetti, A.Amato, V.Fonti, S.Ubaldini, I.De Michelis, B.Kopacek, F.Veglio, F.Beolchini, Waste Management 42 (2015) 180-187

[32] K. Scott, Electrochemical Processes for Clean Technology, Published by the Royal Society of Chemistry, London, UK, 1995. ISBN 10: 0854045066

[33] F. Fu, Q. Wang, Journal of Environmental Management, 92 (2011) 407-418.

[34] V.K. Gupta, O. Moradi, I. Tyagi, S. Agarwal, H. Sadegh, R. Shahryari-Ghoshekandi, A.S.H. Makhlouf, M. Goodarzi, A. Garshasbi, Environmental Science and Technology, 46 (2016) 93118.

[35] D. Choi, Y.S. Kim, Y. Son, RSC Advances, 4 (2014) 50975-50980. 
[36] M. Zelić, M. Mlakar, M. Branica, Analytica Chimica Acta, 289 (1994) 299-306.

[37]X. Li, C. Wei, Z. Deng, C. Li, G. Fan, H. Rong, F. Zhang, Separation and Purification Technology, 156, Part 2 (2015) 348-355.

[38] R. Piercy, N.A. Hampson, Journal of Applied Electrochemistry, 5 (1975) 1-15.

[39] N.G. Yasri, A.J. Halabi, G. Istamboulie, T. Noguer, Talanta, 85 (2011) 2528-2533.

[40] N. Yasri, A.K. Sundramoorthy, W.-J. Chang, S. Gunasekaran, Frontiers in Materials, 1 (2014) 1-10.

[41]A.J. Chaudhary, S.O.V. Dando, S.M. Grimes, Journal of Chemical Technology \& Biotechnology, 76 (2001) 47-52.

[42]A.J. Chaudhary, J.D. Donaldson, S.M. Grimes, N.G. Yasri, Journal of Applied Electrochemistry, 30 (2000) 439-445.

[43] A.J. Chaudhary, M. ul.Hassan, S.M. Grimes, Journal of Hazardous Materials, 165 (2009) 825-831.

[44] A.J. Chaudhary, S.M. Grimes, Chemosphere, 72 (2008) 1636-1642.

[45] S.M. Grimes, J.D. Donaldson, A.J. Chaudhary, M.-U. Hassan, Environmental Science \& Technology, 34 (2000) 4128-4132.

[46] A.J.Chaudhary, S.M.Grimes, M.ul-Hassan, Chemosphere 44 (2001) 1223-1230

[47] B.S. Boyanov, J.D. Donaldson, S.M. Grimes, Journal of Chemical Technology \& Biotechnology, 41 (1988) 317-328.

[48] S.E. Schweikher, Google Patents, 1946.U.S2736692A

[49] A.S. Fouda, L.H. Madkour, M.E. Khalifa, Bulletin De La Societe Chimique De France, (1986) 504-506. 